\title{
Urban-rural linkages as an urban survival strategy among urban dwellers in Botswana: the case of Broadhurst residents
}

\author{
Gwen N. Lesetedi
}

\section{Introduction}

Urban dwellers, particularly the urban poor, maintain strong linkages with the rural areas as a survival strategy. The strengthening and adaptation of urban-rural linkages represents vital safety valves and welfare options for urban people who are vulnerable to economic fluctuations. As an economic survival strategy, urban-rural linkages have assumed new importance with rising urban poverty across most of Africa (O'Connor, 1991). Urban poverty is now thought to surpass rural poverty in many African countries. The precarious economic situation in most African cities is likely to enhance the significance of urban-rural social ties. In the city most migrants, even when they manage to support a family, enjoy little economic security and at times face uncertain political conditions. Unemployment and underemployment are widespread but there is no unemployment compensation. For many migrants, therefore, links with the village of birth provide the only source of economic security. Not knowing when they may experience an economic setback in the city, they maintain ties with villagers as a resource pool that can be taken advantage of during bad times. Such ties assure them a measure of security, which is more reliable than what the city offers most of its citizenry.

The focus of this paper is the nature and extent of urban-rural linkages that characterise the residents of Broadhurst in Gaborone, Botswana and how these can be perceived as a survival strategy. It utilises data from a household survey conducted amongst the residents of Broadhurst. The paper is organised into four sections. The first section presents a broad overview of urbanrural linkages across sub-Saharan Africa while section two discusses the methodology utilised by this study. Section three focuses on the urban-rural linkages construed in terms of property ownership and involvement in economic activities in rural areas; participation in social activities; exchange of money, goods, and visits; and advice-seeking patterns. The third section presents the conclusions

\section{Urban-rural linkages: an overview}

Most urban migrants in Africa live in a dual system characterised by one family but two households. According to Oucho (1996), urbanisation has divided families into two geographically separated but mutually supportive households; one in the urban area and the other in the rural area. Across most of Africa, the separation of men from their wives and children remains widespread especially among low-income earners (Gugler, 1996; Potts, 1997; Findley, 1997). This practice can be traced to the colonial period. As Potts (1997) pointed out, most of the areas in African towns were considered to be European areas and a range of policies were utilised to ensure that African workers migrated to town as temporary "single" male migrants rather than as permanently settled families.

Studies reveal that movement to the city does not mean a sharp break with one's community of origin. Although in the process of moving between villages and cities individuals develop new social relationships, old ones are seldom dissolved; rather they are merely altered (Chant and Radcliffe, 1992; Potts, 1997). Migrants continue to regard themselves as part of their original household in the rural areas. They make frequent visits to their home place, feel some obligation to extend financial assistance to those left behind and plan to eventually return permanently. The maintenance of close ties with home communities has been strengthened by modern communication particularly transport, postal and telephone links.

In a study carried out by Andreasen (1990) it was found that urban dwellers in Kenya, and particularly low-income earners, lacked a commitment to town. People were in town for the money they earned and planned to leave town upon retiring. Even as urban jobs became increasingly a lifetime commitment, urban dwellers never wished to give up the rural household. Having a wife and children at home (in the rural village) was considered to have many advantages (such as looking after land and other family interests) particularly among low-income earners. The Andreasen (1990) study also found the desire to own land in rural areas to be very high especially among male Kenyan urban dwellers. Most men studied had access to land in rural areas and about 
two thirds of all urban families, regardless of their social standing, had access to the same. Those studied also gave the highest priority to building a house in the rural areas.

The system of land tenure in most African countries also encourages strong links to rural areas even for urban migrants. While the freehold system allows for the private ownership of land and makes land accessible to virtually every adult member of the population, land owned by families is usually shared among all members and passed from one generation to the next. Land accessibility (or ownership) in the rural areas by urban dwellers keeps them linked to these areas. Such land is often seen as security when there is no employment in urban areas. Furthermore, in most African countries, land as an asset is characterised by being small, scattered and poorly defined in terms of property rights (Mabogunje, 2000). This results in the marginalisation of land from the mainstream of economic transactions both in the urban and rural areas. A migrant moving from the rural to the urban area cannot sell his land rights in order to have some initial income with which to start a new life in the city. The same land cannot be used as collateral to raise the credit needed for raising the productivity of the land.

According to Kerven (1980), urban-rural connections in Botswana also guarantee migrants a place to 'rest' and be fed in between jobs or during the process of a job search and help migrants to invest accumulated capital particularly in the form of cattle rearing. Upon retirement, many migrants return to the rural areas because they consider rural living to be cheaper and more pleasant. These linkages reflect the immense social and economic importance of family and kinship networks in underpinning and shaping the migration process. Based on this, there are two types of links maintained by migrants. First, those which contribute to sustaining households through remittances and/or contributing to an improved quality of life in source areas through the provision of funds for education or agricultural investments. Secondly, links facilitate or foster the eventual displacement of all household or family members to the destination of the original migrants or provide information on job vacancies and general details about urban life (Chant and Radcliffe, 1992). However, links are not unidirectional. While money is sent by urban workers to the villages, in return foodstuffs, meat, fish, vegetables and other farm produce, which are expensive to purchase in towns, are sent in the other direction (Chant and Radcliffe, 1992: 17).

\section{Data collection and sample description}

This study was conducted in Gaborone, the capital city of Botswana. The particular site for the research was Broadhurst, one of the residential and commercial areas of Gaborone and an area which by 2001 accommodated 28.9 percent $(53,677)$ of the city's total population of 186,007 . The study covered the residential neighbourhoods of Phiring (Extension 34), Ledumang (Extension 48), Ginja (Extensions 22 and 29), and Extension 25. Based on the 2001 Population and Housing Census, the population of Phiring was 1,987 persons while that of Ledumang stood at 4,918. During the same period Ginja and Extension 25 had populations of 2,176 and 5,319 persons, respectively. With the exception of Ledumang, which was made up of Self-Help Housing Agency (SHHA) houses only, all research sites are characterised by a mixture of Botswana Housing Corporation (BHC) housing, privately constructed homes built on Surveys and Lands plots, and SHHA houses. BHC housing areas are distinguishable from Surveys and Lands and SHHA areas by having all services provided including tarred roads and street lights. While Surveys and Lands may have all these services, not all areas are serviced. In SHHA areas on the other hand, not all roads are tarred and in some cases even streetlights are absent. Until recently, water to SHHA housing was mainly provided through communal standpipes but this is now changing; SHHA tenants are now required to connect water in their yards. Although, officially, Ledumang is supposed to provide housing to low-income groups, over the years a blend of low-cost, medium cost and even high-income houses have been constructed. Thus like all other research sites, Ledumang also blends three types of housing. The study targeted only low-cost and medium-cost housing.

In all 360 households, i.e. 90 households from each of the areas, were studied. The households studied were selected utilising a multistage random sampling procedure. Stage one involved the selection of four clusters of residential neighbourhoods to be studied. Guided by a map of the Broadhurst suburb demarcating the various residential neighbourhoods in the area, four sites were randomly selected for the study. The second stage of the sample selection process involved the random selection of the households interviewed for the study. The households comprised 1560 members, 764 males and 796 females. 


\section{Characteristics of the Study Sample}

The term household, as utilised in this study, represents a residential unit where people, whether related or not, live together under the same roof. These ranged from a single member to 13 members. The average household size was 4.3 persons. As is evident from Table $1,36.9$ percent of the households had between one and three members, 38.6 percent had four to five members and the remaining 24.4 percent had six or more members. The household members included 764 (49.0 percent) males and 796 (51.0 percent) females.

\section{Table 1. Distribution of Households by Size}

$\begin{array}{llll}\text { Number of Members } & \text { Frequency } & \text { Percentage } & \text { Cumulative Frequencies } \\ 1 & 35 & 9.7 & 9.7 \\ 2 & 46 & 12.8 & 22.5 \\ 3 & 52 & 14.4 & 36.9 \\ 4 & 76 & 21.1 & 58.1 \\ 5 & 63 & 17.5 & 75.6 \\ 6 & 32 & 8.9 & 84.4 \\ 7 & 22 & 6.1 & 90.6 \\ 8+ & 34 & 9.4 & 100 \\ \text { Total } & 360 & 100 & \end{array}$

The household members ranged in age from less than one year old to those who were 85 years old. The mean age was 24.6 years. Table 2 presents a summary of age categories for the household members. As evident from the Table, 25.5 percent of the household members were aged below 15 years while 65.4 percents were aged between 15 and 45 years. Only 9.1 percent were above 45 years of age. The low percentage of household members above the age of 65 years could be an indication that those who reach retirement age actually return to the rural areas. This view is bolstered by the fact that the percentage composition of households also declines significantly with age and particularly after age 45 .

\section{Table 2. Distribution of Household Members by Age Group}

$\begin{array}{llll}\text { Age Group } & \text { Frequency } & \text { Percentage } & \text { Cumulative Percent } \\ \text { Less than 15 years } & 343 & 25.5 & 25.5 \\ 15 \text { to } 25 \text { years } & 449 & 32.0 & 57.5 \\ 26 \text { to 35 years } & 315 & 22.5 & 80.0 \\ 36 \text { to } 45 \text { years } & 146 & 10.9 & 90.9 \\ 46 \text { to 55 years } & 74 & 5.6 & 96.5 \\ 56+\text { years } & 48 & 3.5 & 100.0 \\ \text { Total } & 1409 & 100 & \end{array}$


Gwen N. Lesetedi

Most (72.2 percent) of the household members were born in the rural areas within Botswana; only 26.0 percent were born in urban areas whereas the remaining 1.8 percent were born outside Botswana. Of those born in the urban areas only, 21.1 percent of household members were born within Gaborone. This means that the majority of those studied were migrants mainly from rural areas. The data further showed that 92.7 percent of household members who were not household heads were blood or marriage relations of the household heads. While 13.6 percent were spouses/ partners to the household heads, 49.4 percent were sons/daughters, 10.9 percent were brothers/ sisters, 5.3 percent were nephews/nieces, 5.1 percent were grandchildren, 4.7 percent were cousins and 3.7 were 'other' relations. Only 7.3 percent were not related at all to the household heads.

\section{Urban Rural Linkages}

Urban-rural linkages can be understood as the structural social relationships maintained between individuals in the urban environment and those in rural areas. The respondents' links to especially rural areas were established by asking whether they owned property, engaged in economic activities, and participated in social activities in the rural areas. The exchange of money, goods, and visits, frequency of communication with relatives and friends, and consultation with people living in rural areas were also used as indicators of urban-rural linkages.

It was felt that it was necessary to establish first whether the respondents still had family members residing in their village of origin. They were asked to give an indication of how many of their family members were residing in the home village. By family members it was meant anyone related to the respondent by blood or marriage. The results showed that all respondents had family members residing in the rural areas. While 53.3 percent of the respondents indicated that most of their family members resided in the home village, 26.1 percent reported that all of their family members lived here in Gaborone. The rest (20.6 percent) had only a few family members residing in the home village. In addition, most respondents were categorical that they had no plans to have rural relatives join them in the urban area. To illustrate, the bulk (71.1 percent) of them fell within this category, 9.4 percent indicated that they were unsure, the rest reported that they wished their relatives to join them in the distant future (9.4 percent), soon, (6.4 percent), or very soon (3.6 percent).

The respondents expressed diverse views about the effects of urban residence on ties with family members in rural areas. However, the majority felt that family ties are stronger in the rural areas compared to the urban areas. While 11.7 percent of the respondents felt that such ties were weakened by urban residence, 40.6 percent considered urban residence to have had no effects on such ties. The rest (47.8 percent) felt that urban residence had strengthened social ties with ruralbased family members. Comparing social bonds in urban areas with those in rural areas, 62.2 percent of the respondents felt that these were stronger in rural. Another 24.2 percent considered social bonds to be equally strong in both urban and rural areas, and 13.6 percent felt that social ties were stronger in urban areas as opposed to rural areas. It was against this background that the urban- rural linkages were analysed.

In addition, the research also sought the respondents' views about future residence in urban areas, the effects of urban residence on family ties, and the strength of social factors in urban versus rural areas. Most respondents planned to retire to their home villages and wished to be buried there. Among the principal respondents, 72.8 percent saw the urban area as a place for work; their real home was in the village. Although 18.9 percent of those studied desired to retire and be buried in the village, this was not mandatory for them. Only 8.3 percent considered town to be their home and wanted to spend their entire life here. This could be further tied to the issue of how the respondents had acquired the housing units they were residing in. The majority of the households resided in rented housing units i.e. 54.4 percent, while 25.0 percent had been ownerbuilt, 16.4 percent had been purchased and only 4.2 percent had been inherited. Of the rented houses, 68.5 percent were rented from private landlords, 25.4 percent from BHC and 6.1 percent from friends and relatives. This reinforced the view that town was just a place to work and therefore respondents preferred to live in rented units. 


\section{Ownership of Property and Involvement in Economic Activities}

The first indicator of urban-rural linkages utilised by this study was the respondents' ownership of property and involvement in economic activities in the rural areas. The survey showed that virtually all respondents owned (91.9 percent) property in rural areas either personally, through a spouse, or through a family member. With respondents owning more than one type of property, the range of properties owned included residential plots, housing, farmland/ fields, livestock, cattle posts/grazing fields, business plots, and other types of properties. Table 3 presents the distribution of respondents by types of property owned. Those who owned land were asked to indicate how they acquired it. The survey showed that 34.2 percent had inherited the land, 33.3 percent owned tribal/communal land, 19.7 percent were allocated land by the Land Board, 8.3 percent owned freehold land, and 4.3 percent had leased it from other persons. Only 8.1 percent of the principal respondents did not own any property in rural areas.

\section{Table 3. Ownership of Rural Property among Principal Respondents}

$\begin{array}{lll}\text { Type of Property } & \text { Frequency } & \text { Percentage } \\ \text { Residential plots/housing } & 253 & 70.3 \\ \text { farmland/fields } & 253 & 64.7 \\ \text { Livestock } & 230 & 63.9 \\ \text { Cattle posts/grazing fields } & 204 & 56.7 \\ \text { Business plots } & 52 & 14.4 \\ \text { Other types of property } & 34 & 9.4\end{array}$

Concerning involvement in economic activities in rural areas, the surveys revealed that respondents were involved in a variety of economic activities including cattle rearing, keeping of small stock (sheep and goats), poultry farming, and arable agriculture, in their village. Of the 360 respondents, 82.2 percent indicated that they were involved in economic activities. With some of the respondents participating in more than one activity, 56.9 percent were involved in farming, 50.0 percent were practising livestock rearing, 16.7 percent were involved in business, and 10.3 percent reported being engaged in other economic activities.

\section{Participation in Social Activities}

The second indicator of urban and rural linkages was the respondents' involvement in social activities in the rural areas. The study focused on two major types of activities, namely, social ceremonies, such as weddings and funerals, and civic meetings, such as kgotla and Village Development Committee (VDC) meetings. The VDCs are structures that oversee development in the villages. The kgotla is a local public consultative assembly which is well-rooted in Tswana society (Molutsi, 1998; Somolekae and Lekorwe, 1998). It is made up of the chief, councillors, village development committee members, headmen and community members. It deliberates over matters affecting the community and makes important decisions.

Concerning participation in social ceremonies, those interviewed indicated that they participated considerably in social activities not only in their home villages but also in other villages including their spouses' or partners'. The majority indicated that they especially attended social ceremonies like weddings and funerals and often participated in the organisation and financing of such occasions. Only 3.3 percent indicated that they never took part in weddings and funerals in the rural areas. While 8.6 percent reported that they seldom participated in such ceremonies, 16.1 percent said that they sometimes took part, 36.6 percent participated often, and 35.8 percent very often. According to the respondents, attending funerals is very important because it is part of Tswana tradition. Some respondents were even members of burial societies in their home villages. 
Gwen N. Lesetedi

The respondents also took a keen interest in the development of their villages to the extent that they attended kgotla meetings and participated in the VDC meetings to keep abreast of developments in the village. To illustrate, only 14.4 percent of them indicated that they never participated in kgotla meetings in rural areas. While 16.1 percent said they seldom attended such meetings, 22.2 percent attended sometimes, 28.3 percent often, and 18.9 percent very often. In addition, only 13.1 percent of these respondents indicated that they never attended VDC meetings in the home village; 24.2 percent seldom attended, 35.6 percent sometimes, 17.2 percent often, and 10.0 percent attended very often.

\section{Exchange of Money, Goods, and Visits}

Other indicators of urban-rural linkages utilised by this study were visitation patterns, and the exchange of money and goods between the respondents and individuals (family, kin or friends) resident outside Gaborone. The results showed the existence of strong urban-rural linkages among those interviewed. The strongest indicator of the three measures among the residents of Broadhurst was visitation patterns. During the six months preceding this study two-thirds (66.7 percent) of the respondents had visited relatives and friends for economic or social reasons. The respondents also reported receiving visitors mostly from rural areas. The bulk (76.1 percent) of the visitors received were relatives particularly from the respondents' village of origin. Most (90.4 percent) of the visits were social e.g., attending weddings and funerals or simply to spend time with relatives. However in a number of cases (9.6 percent) visits were for economic reasons such as collecting foodstuffs for consumption in rural areas or to pay workers at the cattle post.

The exchange of money between the respondents and individuals (family, kin or friends) resident in the rural areas was the next strong measure after visitations. However, as a practice of maintaining urban-rural linkages, the exchange of money was not used as extensively as was the exchange of visits. As with visitation patterns, the volume in the flow of money from urban to rural areas was higher than that from rural to urban areas. Only small proportions of the respondents received money from others. Such a finding was not surprising; it is often the urban migrants who remit earnings to their rural homes rather than them receiving money from the same. The limited flow of money from rural areas to urban areas is consistent with the findings by others such as Oucho (1996) and Rakodi (1995) that remittances from rural to urban areas are rare but by no means totally absent. Of those interviewed 31.3 percent had sent money to rural folk during the six months preceding the interviews. Out of this total, 95.0 percent sent money to relatives while 5.0 percent sent it to friends. The purposes for which money was sent included domestic uses such as buying food, paying workers and educational expenses (90.0 percent) and purchase of property and especially livestock ( 10.0 percent). Concerning the receipt of money, only 15.0 percent of the respondents reported that they had done so either from relatives $(87.5$ percent) or friends $(12.5$ percent).

The last practice through which urban-rural ties were reinforced among the residents of Broadhurst was exchange of goods. However, like that observed elsewhere in the rest of Africa (see e.g., Osirike, 1991; Rakodi, 1995; Ferguson, 1999), the practice is not used as extensively as the exchange of visits. Of the three indicators of urban-rural links analysed, the exchange of goods was the weakest form of maintenance of urban-rural linkages. The results indicated that only small proportions of the respondents received goods from the rural areas. As with money, only a small proportion (9.4 percent) of the respondents had received goods from rural areas. While 80.0 percent of the goods were received from relatives, 20 percent originated from friends. Ordinarily, a significant proportion of urban dwellers are expected to receive goods, especially farm produce, from rural areas as reciprocity for money and goods remitted. It is possible that the arid conditions in Botswana are responsible for this trend. Another explanation of this trend could be the nature of the rural economy in Botswana. Given that agriculture occupies a secondary position in rural Botswana and that the country imports, from other Southern African countries, most farm produce consumed by the population, the flow of goods is likely to be biased toward the rural areas. This limits the amounts and variety of goods (farm produce) that are available for such exchanges. This view is bolstered by the fact that the bulk of the respondents ( 86.2 percent) sent goods to rural kin which consisted of clothing and farm produce for domestic use, to strengthen relationships and for sale. 


\section{Advice-Seeking Patterns}

A final measure of urban-rural ties utilised by the study was the respondents' patterns of seeking advice from relatives and friends resident in rural areas. These were analysed in terms of advice sought by the respondents themselves from others and that sought by others from the respondents. The former focused on the frequency at which the respondents consulted relatives and friends on matters relating to family, social, work, and financial issues while the latter examined whether relatives and friends consulted the respondents on the same issues. The respondents indicated that they sought advice from relatives and friends on matters related to family, social life, work, and finance. Relatives were mainly consulted with respect to matters that they considered confidential or family-related. According to the respondents, they did not feel comfortable discussing such matters with individuals who were not close kin. The relatives consulted included parents, siblings (brothers and sisters), uncles, and adult children. The respondents mainly consulted on issues concerning family matters, social matters and financial matters, at least once during the six months preceding the interviews. The frequency of consultation ranged from once to over 6 times. Concerning advice sought from friends, most of the respondents sought advice on family matters and social matters.

Overall, the results on advice seeking by respondents suggest that they consulted others in rural areas most frequently on family matters and least frequently on work and financial matters. In addition, relatives were the most frequently consulted particularly when it comes to family and social matters. Various forms of communication were utilised by the respondents when seeking advice from relatives and friends. While 55.5 percent of those consulting relatives used face-toface communication, 21.9 percent used third party, 12.8 percent telephone, and 9.8 percent relied on both face-to-face and third party. On the other hand, those consulting friends included 47.8 percent who relied on face-to-face encounters, 34.6 percent who consulted through a third party, and 17.3 percent who utilised the telephone.

The respondents were also asked to indicate whether others resident in rural areas had consulted for advice during the six-month period prior to the study. Over 83.6 percent of the respondents had provided relatives with advice on family matters, 73.9 percent on social matters, 80.0 percent on work issues, and 80.8 percent had been consulted by relatives on financial matters. Concerning the provision of advice to friends, 36.7 percent of the respondents had advised friends on family matters, 48.3 percent on social matters, 66.4 percent on work issues, and 47.5 percent on financial matters, at least once during the six-month period previous to the study. The modes of communication utilised by those seeking advice from the respondents included face-to-face, third party, telephone, letters, and a combination of face-to-face and third party.

\section{Conclusions}

The residents of Broadhurst still maintain strong urban-rural linkages as evident from the study findings that those studied had not severed their ties with their rural kin. The study found that most respondents owned property in their rural villages and were involved in various types of economic activities. They also participated in social activities including funerals and weddings, and in civic activities such as attending kgotla meetings and VDC meetings. Most of the respondents were migrants from rural areas and had the majority of their relations resident in these areas. As such, they maintained strong social links with rural kin through the exchange of money, goods and visits. This in most cases took the form of urban residents sending money and goods to rural kin. Most important, the respondents frequented their rural villages of origin and received visitors from the village.

The existence of strong urban-rural linkages may be a reflection of the fact that most of the respondents were born in the rural areas. Consistent with urban social networks, such urban-rural linkages are also expected to strengthen in the future. The key pointer to this conclusion is the rising unemployment characteristic of most African countries, Botswana included, which dictates that migrants retain ties with rural kin as social and economic security. As unemployment and general economic uncertainty rise in most African cities, urban-rural ties are likely to grow in strength. Lack of access to land and credit facilities in urban areas, especially for low-income groups, inclines the migrant to maintain ties with rural areas for the purpose of accessing land, a very valued resource among African populations. Villagers, on the other hand, value strong ties with urban dwellers because they may need to rely on them for help. Urban dwellers often stressed the need for the maintenance of rural links as an economic security for the eventualities of old age 


\section{Gwen N. Lesetedi}

and unemployment. The strength of attachment to rural areas by these respondents was not only manifested through these practices but also through a desire to return to the village in the future. Virtually all those interviewed were categorical that they planned to retire to and wished to be buried in the village of origin. For them life in town was temporary and the village was their actual home.

\section{References}

Andreasen, J.

1990. "Urban-Rural Linkages and their Impact on Urban Housing in Kenya.” In J. Baker (ed.), Small Town Africa: Studies in Rural Urban Interaction. Seminar Proceedings No. 23,

Scandinavian Institute of African Studies, Uppsala.Baker, J. 1986. The Rural-Urban Dichotomy in the Developing World. London: Norwegian University Press.

Chant S., and Radcliffe, S. A.

1992. "Migration and Development: The Importance of Gender", in S. Chant (ed.) Gender and Migration in Developing Countries, London: Belhaven Press, pp 1-29.

Ferguson, J.

1999. Expectations of Modernity: Myths and Meanings of Urban Life on the Zambian Copper Belt. Berkeley, CA.: University of California Press.

Findley, S. E.

1997. "Migration and Family Interactions in Africa." In A. Adepoju (ed.), Family, population and development in Africa. London: Zed Books. Pp. 109-138

Geschiere, P. and Gugler, J.

1998. "The Urban-Rural Connection: Changing Issues of Belonging and Identification." Africa, 68 (3): 309-319.

Gitau, W. G.

1995. "Modernity and its Discontents: An Exploratory Study of Kenyan Elites' Perceptions of the Effects of Modernisation on Individual and Family Life", UMI Dissertation Services, Ann Arbor, Michigan.

Gugler, J.

1996. "The Urban Transformation of the Developing Countries" in J. Gugler (ed.) The Urban

Transformation of the Developing World. New York: Oxford University Press.

Hesselberg, J.

1993. "Urban Low-Income Groups' Economic Strategies and Linkages to Rural Areas: The Case of Botswana." In Dahl et al. (eds.) Land, Food and Basic Needs in Developing Countries.

Department of Human Geography, University of Gothenburg, Series B, pp. 160 - 172.

Hummon D.M.

1986. “Urban Views Popular Perspectives on City Life”, Urban Life, Vol. 15 No. 1:3-36.

Kerven, C.

1980. "Rural-Urban Interdependence and Agricultural Development", in R. R. Hitchcock and M. R. Smith M.R. (eds.) Proceedings of the Symposium on Settlement in Botswana: The Historical Development of a Human Landscape. Gaborone: Botswana Society, pp. 234-244.

Klu, F. F.

1990. "Urban Migration and Its Linkages in Selected Urban Systems in Liberia: Policies, Issues and Considerations", in UAPS, Spontaneous Contributions to the Conference on The Role of Migration in African Development, Nairobi, Kenya: Union for African Population Studies, pp. 
$505-534$.

Larson, A.

1998. "Housing as a Strategy for Urban-Rural Linkages in Botswana." In A. Larson, M. Mapetla and A. Schlyter (eds.) Changing Gender Relations in Southern Africa: Issues of Urban Life. Lesotho: Institute of Southern African Studies, National University of Lesotho, pp 129-153.

Mabogunje, A. L.

2000 "Global Urban Futures: An African Perspective”. Urban Forum, 11 (2): 165-184.

Netting Robert $\mathrm{McC}$ et. al.

1984. Households: Comparative and Historical Studies of the Domestic Group. Berkeley:

University of California Press, Ltd.

Obbo, C.

1980. "Strategies for Urban Survival", in African Women: Their Struggle for Economic

Independence, London: Zed Press, pp. 101 - 121.

O'Connor A.

1991. Poverty in Africa: A Geographical Approach. London: Belhaven Press.

Osirike, A. B.

1991. "Migration, Dual Residence and Survival Strategy in a Depressing Rural Economy: A Study of Migrants' Families in Bendel State, Nigeria", in UAPS Spontaneous Contributions to the

Conference on the Role of Women, Family and Population at Ougadougou, Burkina Fasso, April

24-29, 1991, Union of Africa Population Studies, Vol. 2, pp. 227-239.

Oucho, J.O.

1996. Urban Migrants and Rural Development in Kenya. Nairobi: Nairobi University Press.

Potts, D.

1997. "Urban Lives: Adopting New Strategies and Adapting Rural Links." In C. Rakodi (ed.), The

Urban Challenge in Africa: Growth and Management of Its Large Cities. New York: United

Nations [Pp. 447-494]

Rakodi, C.

1995. Harare, Inheriting a Settler-Colonial City: Change or Continuity. Chichester: John Wiley and Sons.

Trager, L.

1998. "Home-Town Linkages and Local Development in South-Western Nigeria: Whose Agenda? What Impact?" Africa, 68 (3): 360 - 382.

United Consulting Ltd.

1997. Gaborone City Development Plan (1997-2021), Draft Final. (UCL, 1997) Gaborone:

Ministry of Local Government, Lands and Housing.

United Nations.

1994. World Social Situation in the 1990s. New York: United Nations.

Vanderpost, C.

1995. "Migration, Population Distribution and Urbanisation in Botswana" paper presented at the National Conference on Population Policy Consideration in Botswana's Development at the Grand Palm Hotel Gaborone 30th October-2nd November, 1995. 
Gwen N. Lesetedi Abstract
This paper studies the role of urban-rural linkages as survival strategies and as a form of
economic security in the face of increasing levels of urban unemployment. The study focuses on
the residents of Broadhurst, a suburb of Gaborone, Botswana and presents the result of a survey of
360 households. The households contained 1560 people of whom $90.9 \%$ were 45 years old or less.
Urban-rural linkages included the continuation of part time work and residence in the rural area
and the continued management of land and livestock in the rural area. In all, 91.9\% of the
households interviewed owned property in rural areas while $70.3 \%$ owned residential land, $64.7 \%$
owned farmland, $63.9 \%$ owned livestock, $56.7 \%$ owned grazing lands, $14.4 \%$ owned business
plots and an additional $9.4 \%$ owned other forms of rural property. Linkages with the rural area
were reinforced through participation in social activities, exchange of goods and services, and the
consultation with rural people primarily over family matters and the consultation by rural relatives
on work or financial matters.

Key words: urban-rural linkages, survival strategy, economic security, Botswana, Gaborone, Broadhurst, rural-urban migration, migrants, land tenure, property, livestock, household, rural development, urban survey.

\section{Resumé}

Cet article étudie l'importance des liens ville-compagne comme stratégie de survie et sécurité économique en face des niveaux accroissant de sous-emploi urbain. L'étude regarde les résidants de Broadhurst, un faubourg de Gaborone, Botswana et présente les résultats d'une enquête de 360 ménages. Les ménages englobent 1560 peuple dont 90,9\% ont 45 ou moins ans. Les liens ville compagne incluent la continuation des travaux ou résidence à temps parti et l'administration des terres et des troupeaux dans la compagne. En tout, 91,9\% des ménages interviewés étaient propriétaire dans la compagne tandis que $70,3 \%$ étaient propriétaire des terrains résidentiels, 64,7\% avaient des terrains agricoles, $63,9 \%$ avaient des troupeaux, 56,7\% avaient des terres à pâturage, 14,4\% avaient des lotissements pour les affaires et un autre 9,4\% avaient d'autres immobiliers. Liens avec la compagne étaient fortifiés à travers les activités sociales, l'échange des biens et des services, et à travers la consultation avec les ruraux au sujet des affaires de la famille et la consultation des ruraux avec les résidants de Broadhurst au sujet des matières financières ou liés à travail.

Mots clefs: liens ville-compagne, stratégie de survie, sécurité économique, Botswana, Gaborone, Broadhurst, migration compagne-ville, migrants, régime foncier, la propriété, les troupeaux, ménages, développement rural, enquête urbaine.

\section{Resumen}

El presente trabajo estudia el rol de las conexiones urbano-rurales como estrategias de sobrevivencia y como formas de resguardo de la seguridad económica ante el incremento en los niveles del desempleo urbano. El estudio se enfoca en los residentes de Broadhurst, un suburbio de Gaborone, Botswana y presenta los resultados de una encuesta aplicada a 360 hogares. Los hogares representan un total de 1560 personas de las cuales $90.9 \%$ tenía 45 años de edad o menos. Las conexiones Urbano-rurales incluían la mantención de un trabajo asalariado de semi-tiempo y residencia en el área rural junto con la continuidad del manejo de tierra y ganado en el área rural. De todos, $91.9 \%$ de los hogares entrevistados eran propietarios de tierra en áreas rurales mientras $70.3 \%$ poseía propiedad residencial, $64.7 \%$ eran dueños de tierras agrícolas , $63.9 \%$ poseía ganado, $56.7 \%$ eran dueños de pastizales , $14.4 \%$ poseían parcelas para negocios y el restante $9.4 \%$ eran dueños de otras formas de propiedad rural. Las conexiones con la zona rural eran reforzadas a través de la participación en actividades sociales, intercambio de bienes y servicios, y consultas con gente del campo principalmente sobre asuntos familiares además de la consulta de familiares en la zona rural sobre trabajo o asuntos financieros.

Palabras claves: Conexiones urbano-rurales, estrategia de sobrevivencia, seguridad económica, Botswana, Gaborone, Broadhurst, migración urbano-rural, migrantes, tenencia de la tierra, propiedad, Ganado, hogar, desarrollo rural, encuesta urbana. 